presumably an increase in membrane permeability to sodium. Regardless of the initiating factor, however, the next steps are identical-namely, increased sodium efflux and potassium influx leading to a return to normal of cell potassium.

The significance of the disturbances in cellular sodium homoeostasis is not clear, but if we assume that the changes in the sodium content of leucocytes are found in other cells then our findings may be relevant to the production or maintenance of hypertension. Increased sodium in smooth muscle has long been thought to cause the increase in peripheral resistance which is uniformly found in hypertension. Our findings indicate that there may be a different pattern of derangement of cellular sodium homoeostasis in black patients with hypertension.

\section{References}

${ }^{1}$ Eyer J. Hypertension as a disease of modern society. Int $\mathcal{f}$ Health Serv $1975 ; 5: 539-58$.

2 Dahl LK, Love RA. Relation of sodium chloride intake to essential hypertension in humans. Fed Proc 1954;13:426.

${ }^{3}$ Dahl LK, Love RA. Evidence for relationship between sodium (chloride) intake and human essential hypertension. Arch Intern Med 1954;94: 525-31.

4 Dahl LK, Heine M, Tassinari L. Effects of chronic excess salt ingestion: evidence that genetic factors play an important role in susceptibility to experimental hypertension. F Exp Med 1962;115:1173-90.

${ }^{5}$ Garay RP, Meyer P. A new test showing abnormal net $\mathrm{Na}^{+}$and $\mathrm{K}^{+}$fluxes in erythrocytes of essential hypertensive patients. Lancet 1979; i:349-53.

${ }^{6}$ Canessa M, Adragna N, Solomon HS, Connolly TM, Tosteson DC. Increased sodium-lithium countertransport in red cells of patients with essential hypertension. $N$ Engl f Med 1980;302:772-6.

7 Edmondson RPS, Hilton PJ, Thomas RD, Patrick J, Jones NF. Abnormal leucocyte composition and sodium transport in essential hypertension. Lancet $1975 ; \mathrm{i}: 1003-5$.

${ }^{8}$ Baron DN, Ahmed SA. Intracellular concentrations of water and of the principal electrolytes determined by analysis of isolated human leucocytes. Clin Sci $1969 ; 37: 205-19$.

9 Blaustein MP. Sodium ions, calcium ions, blood pressure regulation and hypertension: a reassessment and a hypothesis. Am $\mathcal{F}$ Physiol 1977 ;232: C165-73.

10 Tobian L. How sodium and the kidney relate to the hypertensive arteriole. Fed Proc 1974;33:138-42.

11 Patrick J, Hilton PJ. Characterization of sodium transport disorders in disease: different effects upon sodium and potassium of changes in the sodium pump and in membrane permeability. Clin Sci 1979;57:289-93.

(Accepted 30 March 1981)

\title{
Effect of naftidrofuryl on the metabolic response to surgery
}

\author{
H J G BURNS, D J GALLOWAY, I McA LEDINGHAM
}

\begin{abstract}
In a randomised study of 34 patients undergoing elective operations of moderate severity naftidrofuryl infusion significantly improved postoperative nitrogen balance. The control group excreted $26.2 \pm 2.7 \mathrm{~g}$ nitrogen in the first three postoperative days. A group treated with naftidrofuryl excreted $18.0 \pm 1.6 \mathrm{~g}$ nitrogen in the same period $(p<0.0005)$. The preoperative nutritional state of patients treated with naftidrofuryl did not differ from that of the controls.

Though hormonal changes causing an improvement in nitrogen balance could not be excluded by this study, the results show that naftidrofuryl infusion may stimulate postoperative catabolism of endogenous carbohydrate and fat, thus sparing tissue protein.
\end{abstract}

\section{Introduction}

Increased urinary excretion of nitrogen and reduced synthesis of tissue protein are accepted features of the metabolic response to injury. ${ }^{12}$ It is widely recognised that this alteration in protein metabolism leads to increased morbidity and mortality in injured patients, and hyperalimentation with protein and energy sources has been advocated as a means of improving prognosis after surgery. ${ }^{3}{ }^{4}$ Though intensive nutritional support may

\footnotetext{
University Department of Surgery, Western Infirmary, Glasgow G11 6NT

H J G BURNS, MB, FRCs, lecturer in surgery

D J GALLOWAY, MB, CHB, senior house officer (now surgical registrar, Royal Alexandra Infirmary, Paisley)

I MCA LEDINGHAM, MD, FRCSED, FRSE, professor
}

improve nitrogen balance postoperatively, the evidence that it will significantly alter outcome remains unconvincing. Several workers have suggested that inhibition of intracellular metabolic pathways may be the basis of abnormal protein metabolism after injury..$^{5-7}$ Pharmacological stimulation of cellular metabolism may therefore be a more specific means of improving nitrogen balance. Naftidrofuryl (Praxilene) may stimulate cellular metabolism after injury. We decided to investigate the possibility that this drug might modify postoperative nitrogen metabolism.

\section{Patients and methods}

Informed consent was obtained from 34 patients undergoing elective operations of moderate severity. Only patients who reported no preoperative weight loss were considered for study. They were weighed and their skinfold thicknesses measured in the four positions described by Durnin and Rahaman. ${ }^{8}$ These measurements were used to derive fat-free mass. They were then randomised into a control group or a treatment group according to the last digit of their hospital case number. On the morning of operation a 24-hour urine collection was started, and daily collections were continued for the study period, which was three days. Total urinary nitrogen was estimated by the method of Fleck. ${ }^{9}$ Plasma urea and electrolyte concentrations were measured daily.

Both groups received similar amounts of blood in the perioperative period and a standard fluid regimen consisting of isotonic dextrose and saline for three days postoperatively. Only water was permitted by mouth. During the study the treatment group received twice-daily infusions of $200 \mathrm{mg}$ naftidrofuryl given over one to two hours. The first infusion began with the induction of anaesthesia. A standard anaesthetic technique was used throughout.

\section{Results}

The 19 control patients undergoing operations of moderate severity excreted $26.2 \pm 2.7 \mathrm{~g}$ (mean \pm 2 SEM) of nitrogen in the three days 
after operation. Fifteen patients who received twice-daily infusions of $200 \mathrm{mg}$ naftidrofuryl excreted $18.0 \pm 1.6 \mathrm{~g}$ of nitrogen during the same period. This difference was highly significant $(p<0.0005)$. There was no difference between the two groups in sex distribution or age, and the operations performed were of similar severity (table I). There was no difference in preoperative nutritional state between the two groups (table II). The 5\% dextrose content of our standard fluid regimen provided a mean of $1.61 \pm$ SEM $0.46 \mathrm{MJ}(385 \pm 110 \mathrm{kcal})$ daily in the control group and $1.50 \pm 0.52 \mathrm{MJ}(360 \pm 125 \mathrm{kcal})$ daily in the naftidrofuryl-treated group. This difference was not significant.

TABLE I-Age, sex distribution of studied patients, and operative procedures carried out

\begin{tabular}{|c|c|c|}
\hline & Control group $(n=19)$ & Treatment group $(n=15)$ \\
\hline $\begin{array}{l}\text { M:F } \\
\text { Mean age (range) } \\
\text { Operation }\end{array}$ & $\begin{array}{l}8: 11 \\
47(18-64) \\
\text { Cholecystectomy }(n=10) \\
\text { Vagotomy and drainage }(n=4) \\
\text { Mastectomy }(n=2) \\
\text { Colectomy }(n=1) \\
\text { Small-bowel resection }(n=1) \\
\text { Staging laparotomy }(n=1)\end{array}$ & $\begin{array}{l}6: 9 \\
55(24-75) \\
\text { Cholecystectomy }(n=5) \\
\text { Vagotomy and drainage }(n=2) \\
\text { Mastectomy }(n=1) \\
\text { Colectomy }(n=4) \\
\text { Small-bowel resection }(n=1) \\
\text { Gastrectomy }(n=2)\end{array}$ \\
\hline
\end{tabular}

TABLE II-Anthropometric data of patients studied

\begin{tabular}{|c|c|c|c|}
\hline & & Control group & Treatment group \\
\hline 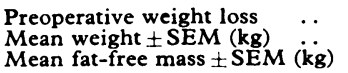 & $\begin{array}{ll}. . & \cdots \\
\because & \cdots\end{array}$ & $\begin{array}{c}0 \\
64 \cdot 8 \pm 5 \cdot 7 \\
51 \cdot 6 \pm 7 \cdot 0\end{array}$ & $\begin{array}{l}0 \\
60 \cdot 1 \pm 8 \cdot 5 \\
46 \cdot 9 \pm 8 \cdot 8\end{array}$ \\
\hline
\end{tabular}

To rule out an effect of naftidrofuryl on renal function we measured the daily urea clearance in six control and six treated patients (see table III). There was no difference between the two groups. This agrees with the study of Heidrich et al, which showed no effect of naftidrofuryl on renal function after 14 days of infusion. ${ }^{10}$

TABLE III-Urea clearance in six treated and six control patients

\begin{tabular}{ccc}
\hline 24-hour period & $\begin{array}{c}\text { Control group } \\
(\mathrm{ml} / \mathrm{min} \pm 2 \text { SEM) }\end{array}$ & $\begin{array}{c}\text { Treatment group } \\
(\mathrm{ml} / \mathrm{min} \pm 2 \text { SEM })\end{array}$ \\
\hline Day 1 & $38 \pm 10$ & $36 \pm 13$ \\
Day 2 & $48 \pm 10$ & $51 \pm 15$ \\
Day 3 & $58 \pm 14$ & $54 \pm 12$ \\
\hline
\end{tabular}

\section{Discussion}

Protein catabolism after injury has been intensively investigated because of its potentially serious clinical consequences. Some think that a change in the pattern of hormone secretion after injury or differential tissue sensitivity to hormones may explain at least some of the metabolic sequelae. ${ }^{11} 12$ Alternatively trauma may inibit intracellular metabolic pathways. ${ }^{5-7}$ Mammalian cells produce energy by the oxidation of nutrients in the tricarboxylic acid cycle. Fat is broken down to acetyl coenzyme A, which condenses with oxaloacetate to form citrate. Carbohydrate is metabolised to pyruvate then acetyl coenzyme A, which enters the tricarboxylic acid cycle in the same way as fat. Protein, however, is broken into its constituent amino-acids, which can then enter the tricarboxylic acid cycle by specific pathways which convert them to intermediates of the cycle. ${ }^{13}$ It has been suggested that injury may modify the reactions that control the entry of fat and carbohydrate into the tricarboxylic acid cycle. This would prevent efficient utilisation of fat or carbohydrate for energy production. The only substrate available for oxidation by the tricarboxylic acid cycle would then be those amino-acids which could bypass inhibited reactions. Hence if this inhibition could be overcome an increase in carbohydrate and fat utilisation and a reduction in the amount of nitrogen excreted by an injured patient might be expected.

One drug that may stimulate fat and carbohydrate entry into the tricarboxylic acid cycle is naftidrofuryl. It increases the adenosine triphosphate content of ischaemic muscle ${ }^{14}$ and decreases the amount of lactic acid produced by ischaemic brain. ${ }^{15}$ Also, Shaw and Johnson showed that naftidrofuryl given to normal people during exercise stimulates oxidative respiration of cells. ${ }^{16}$ How naftidrofuryl produces these effects is not clear. Meynaud et al suggested that it frees succinate dehydrogenase from normal control mechanisms which tend to reduce its activity in the injured cell. ${ }^{15}$ Succinate dehydrogenase is not normally thought to be a controlling enzyme for tricarboxylic acid cycle activity, ${ }^{17}$ and naftidrofuryl may have some as yet unknown effect on other controlling points in the cycle.

Infusion of naftidrofuryl in injured patients may therefore stimulate entry of pyruvate or acetyl coenzyme A into the tricarboxylic acid cycle and consequently improve the efficiency of carbohydrate or fat metabolism. This would lead to a reduction in the amount of amino-acid oxidation taking place and therefore reduce nitrogen excretion.

An alternative explanation is that naftidrofuryl produces these effects by altering the hormonal environment after injury. Insulin stimulates membrane transport of glucose into muscle cells. It also promotes protein synthesis. Though naftidrofuryl may cause no alteration in plasma glucose, Meynaud et al suggested that it increases brain cell glucose content. ${ }^{15}$ This might indicate that naftidrofuryl either increases insulin secretion or has an insulin-like activity.

This study was carried out as a preliminary experiment to test our hypothesis that naftidrofuryl might improve nitrogen balance after injury. We think that we have confirmed this. It is the first indication that protein metabolism after injury might be modified by direct pharmacological means. The mechanism of action of the drug remains in doubt, however, and probably further studies of the drug in critically ill patients and of its mode of action are warranted.

\section{References}

${ }^{1}$ Cuthbertson DP. The disturbance of metabolism produced by bony and non bony injury, with notes on certain abnormal conditions of bone. Biochem f 1930;24:1244-63.

2 O'Keefe SJD, Sender PM, James WPT. "Catabolic" loss of body nitrogen in response to surgery. Lancet 1974 ;ii:1035-7.

${ }^{3}$ Mullen JL, Buzby GP, Mathews DC, Smale DF, Rosato EF. Reduction of operative morbidity and mortality by combined preoperative and postoperative nutritional support. Ann Surg 1980;192:604-13.

4 Williams RH, Healtey RV, Lewis MH, Hughes LE. A randomised controlled trial of preoperative intravenous nutrition in patients with stomach cancer. Br $\mathcal{F}$ Surg 1976;63:667.

${ }^{5}$ Burns HJG, Ledingham IMcA, Kay AW. Inhibition of metabolic pathways in Gram negative septicaemia. Br $\mathcal{F}$ Surg 1978;65:360.

6 Ryan NT. Metabolic adaptations for energy production during trauma and sepsis. Surg Clin North Am 1976;56:1073-90.

${ }^{7}$ Border JR, Burns GP, Rumph C, Schenk WG. Carnitine levels in severe infection and starvation: a possible key to the prolonged catabolic state. Surgery 1970;68:175-9.

${ }^{8}$ Durnin JVGA, Rahaman MM. The assessment of the amount of fat in the human body from measurements of skinfold thickness. Br $\mathcal{F}$ Nutr $1967 ; 21$ :681-9.

9 Fleck A. The determination of organic nitrogen. Proceedings of the Association of Clinical Biochemists 1967;4:212-5.

${ }^{10}$ Heidrich H, Baethke R, Blyer K. Investigations of the effect of naftidrofuryl on the serum creatinine and on the PAH/insulin clearance in cases of peripheral arterial disease. Arzneim Forsch 1975 ;25:429-31.

11 Johnston IDH. The metabolic and endocrine response to injury: a review. Br F Anaesth 1973;45:252-5.

12 Wilmore DW. Hormonal responses and their effect on metabolism in response to injury and infection. Surg Clin North Am 1976;56:999-1018.

${ }^{13}$ Lehninger AL, ed. Oxidative degradation of amino acids. Biochemistry: the molecular bases of all structure and function. 2nd ed. New York: Worth, 1975:559-84.

14 Elert C, Niebel W, Karuse E, Satler P. The effect of naftidrofuryl on energy metabolism in the musculature of limbs with impaired blood flow. Therapiewoche 1976;23:3947-50.

15 Meynaud A, Grand M, Fontaine L. Effect of naftidrofuryl upon energy metabolism of the brain. Arzneim Forsch 1973;23:1431-6.

16 Shaw SWJ, Johnson RH. The effect of naftidrofuryl on the metabolic response to exercise in man. Acta Neurol Scand 1975;52:231-7.

17 Ottaway JH. Control points in the citric acid cycle. Biochem Soc Trans $1976 ; 4: 371-6$. 